UDC 621.951.4.025.7:678.7

R.Yu. Melentiev, Master

Odessa National Polytechnic University, 1 Shevchenko Ave., 65044 Odessa, Ukraine; e-mail: melentievr@gmail.com

\title{
THE NEW DESIGNS OF DIAMOND DRILL BITS FOR COMPOSITE POLYMERS TOOLING
}

\begin{abstract}
Р.Ю. Мелентьєв. Нові конструкції алмазних свердел для обробки композиційних полімерів. Автор досліджує процес свердління ряду нових конструкційних матеріалів таких як вуглепластики та інші полімери, що мають анізотропну структуру, високі міцнісні і пружні властивості в поєднанні з низькою теплостійкістю. Таке поєднання властивостей унеможливлює просте перенесення положень існуючих технологій обробки класичних матеріалів на аналізований новий клас. У місці з тим існуючий інструмент не може забезпечувати задану якість обробленої продукції при збереженні колишньої продуктивності та стійкості інструменту. Мета: Метою цього дослідження $€$ підвищення ефективності процесу свердління композиційних полімерів шляхом розробки нових конструкцій алмазних свердел. Матеріали $\boldsymbol{i}$ методи: Одним з найбільш перспективних напрямків у вирішенні даної задачі $\epsilon$ алмазно-абразивний тип інструменту. У роботі розглянуті і класифіковані існуючі типів алмазних свердел за призначенням і принципом роботи. Проведено літературний аналіз відомих недоліків процесу свердління, якості обробленої і прилеглих поверхонь. Результати: Експериментальні дослідження автора доводять негативну значимість вже відомої, але залишаємої в стороні обставини - блокування керна. Виявлено найбільш значущі фактори і конструктивні особливості, які впливають на процес свердління вуглепластиків, при маніпуляції якими, був створений ряд унікальних конструкцій алмазних свердел різного призначення. Представлені запатентовані моделі мають різну схему розподілу припуску та сил різання, чим задовольняють виробничі вимоги до якості, продуктивності, стійкості інструменту та розміру отвору при обробці зазначеного класу матеріалів.

Ключові слова: конструкції алмазних свердел, свердління, вуглепластик, блокування керна.

R.Yu. Melentiev. The new designs of diamond drill bits for composite polymers tooling. The author explores the drilling operation of some new engineering materials such as carbon fiber reinforced plastics (CFRP) and other polymers that have an anisotropic structure, highstrength and elastic properties combined with low heat endurance. Such combination of properties makes impossible the simple transfer of the existing technologies for classic materials working to considered new class. At the same time, the existing tools cannot assure the specified quality of tooled products at the current productivity and tool life. Aim: The aim of this research is to increase the process efficiency of diamond drilling in composite polymers by developing the new designs of diamond drill bits. Materials and Methods: One of the most promising directions to solve this problem is the diamond coated abrasive type tool. This paper addresses and classifies the existing types of diamond drill bits according to their application and operation. The literature data analysis of known disadvantages during drilling operation, the quality of surface and joining face was performed. Results: The experimental researches of the author prove the negative meaning of the already known but kept out fact — the drill core blocking. The most important factors and structural features affecting the CFRP drilling process are revealed. The accounting of these factors allowed creating the set of unique designs of diamond drill bits for different purposes. The presented patented models has different allowance distribution schemes and cutting forces, thus satisfy the mechanical requirements of quality, productivity, tool life and hole geometry in the tooling of the specified material class.

Keywords: designs of diamond drill bits, drilling, carbon fiber reinforced plastic, drill core blocking
\end{abstract}

Introduction. Currently, there is quick growth of non-metallic materials use such as plastics composite materials, glass, ceramics and others. This leads to necessity of methods perfection for these materials working, which is significantly complicated due to special physical and mechanical characteristics of these materials. The hole tooling in non-metallic materials is very time consuming operation. There are many methods for holes tooling in articles from these materials. Among these methods are an ultrasonic treatment by free abrasive, laser and electrochemical machining. The use of specified techniques is very limited due to its high cost, equipment complexity and low productivity of the tooling process. The most effective method is the conventional and diamond drilling.

Nowadays, diamond tools are presented in quite a wide variety. New designs of drill bits appear simultaneously with new materials and high quality requirements. The construction of diamond drill bits can be broke up into two types (Fig. 1): designed specially to get the hole of certain diameter and universal - with varying nominal size. The universal drill bit can consist of replaceable parts and has several accessories to change diameter of a hole. The cutting part of the universal diamond drill bits has one or more cutting elements combined in device, which allows changing the distance between cutting elements and the drill axis. Typically, such drill bits are used for drilling holes of large diameter in small-scale production. For one diameter hole drilling in industrial-scale production, such as

DOI 10.15276/opu.3.47.2015.05

(C) 2015 The Authors. This is an open access article under the CC BY license (http://creativecommons.org/licenses/by/4.0/). 
perforation of sound-absorbing panels, the special purpose drill bit is used. The construction of these drill bits can be shaped as a rod with hollow or be presented as a hybrid of two previous types. Diamond hollow drill bit forms a ring during material working, which width corresponds to the thickness of cutting base. The material, that has been cut out from the ring goes into chip scrap. The material situated near the tool rotation axis is not removed. It gradually turns into piston and passes into the inner space of the tool. Today it is one of the most commonly applicable types of diamond drill bits. The rod drill bit does not form the piston, because it works all material into chip scrap. Such drill bits are using to drill small holes. Recently the hybrid type drills appeared. One of the most popular drill bit is the horseshoe-shaped one [1...3], made in a form close to the horseshoe. This eliminates the problem of the dead point cutting (cutting the zone near the rotation tool axis). One side of the drill bit is open, allowing cleaning the piston automatically. Asymmetrical drills almost do not create the piston, in any case, the piston has a smaller diameter then inner drill bit one. In addition, the asymmetric drill bit as the figured drill bit creates discontinuous cutting condition. The benefits of this condition studied by scientific school of academician A.V. Yakimov [4...6]. It allows heat reduction during a drilling process to improve the conditions of chip scrap removal, to prevent smoothing of diamond cutting edges, to increase the tools performance. There is quite wide range of diamond drill bits designs, but industry produces commercially only two types: core and rob drill bits.

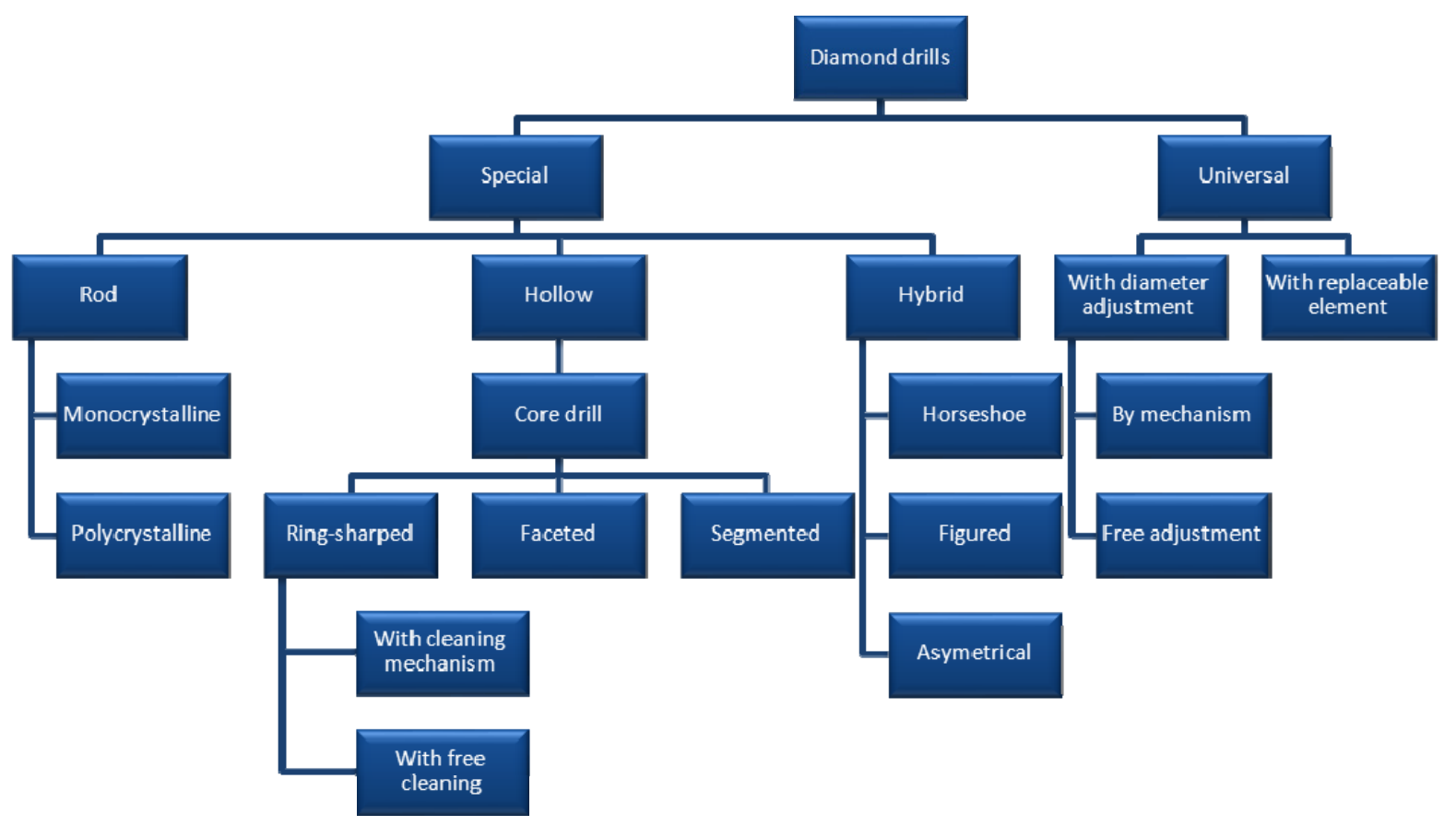

Fig. 1. The classification of diamond drill bits

It should be noted, that some existing drill bits are not related to diamond tools. They are the blade and diamond tools hybrid. These tools are not always produced for commercial purposes, because they do not satisfy the quality requirements for the tooling, have very complex or expensive design. Nevertheless, sometimes it is possible to observe quite interesting options. Quan and Zhong [7] have compared the results of CFRP drilling using diamond-plated solid drill bit and several variants of core drill bit (Fig. 2). The authors noticed that the effect of a plated diamond solid drill bit for drilling and grinding of CFRP is not so satisfactory. The Taiwan research group of C.C. Tsao has created series of special drill bits for the treatment of CFRP [8...13]. The design of each drill bit consists of two counter-rotating drills (Fig. 3): diamond core drill and blade (twist drill, Saw drill and candlestick drill) drill inside. The experimental results show that the cutting velocity ratio, feed rate 
and inner drill type are the most important variables among the five control factors that influence the thrust force. The effect of stretch and inner drill diameter are relatively insignificant. The compound core-special drill bits (contains a driven device) have been found to be more advantageous, such as lower thrust force, lower delamination, lower chip scrap clogging and higher chip scrap removal in compare with the core drill bits and conventional blade types. The comprehensive modeling $[14,15]$ and analysis [16] of special drill bits illustrate advantages of thrust distribution toward the drill bit periphery rather than concentration at hole center (twist drill). In other words, special drill bits can operate at larger feed rate (namely shorter cycle time) without delamination damage as compared to the twist drill.

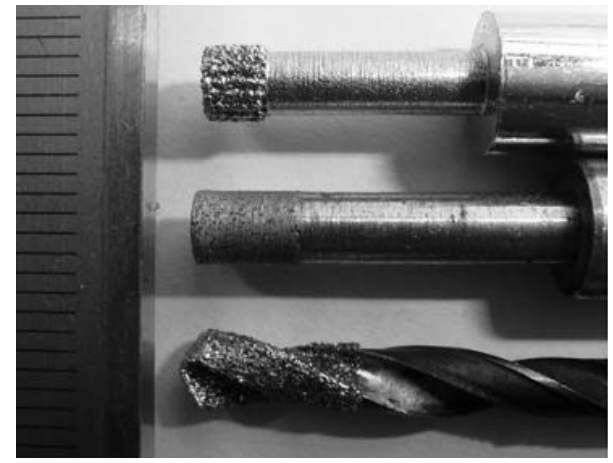

Fig. 2. Drill geometry of [7]. Top: Plated diamond core drill; Middle: Cemented diamond core drill; Bottom: Plated solid drill

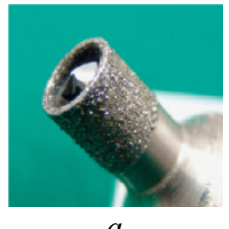

$a$

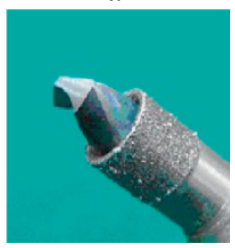

$d$

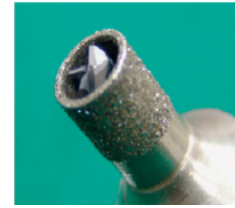

$b$

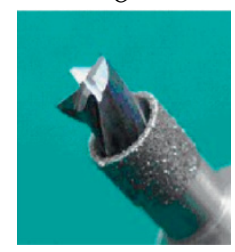

$e$

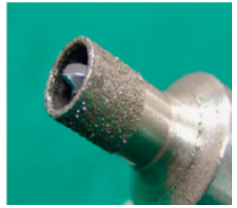

$c$

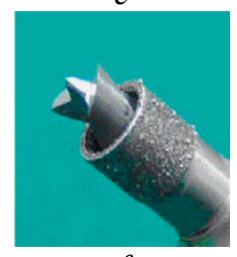

$f$
Fig. 3. Various types of core-special drill bits: (a) Core-twist drill, (b) core-saw drill, (c) core-candlestick drill, (d) step-core-twist drill, (e) step-core-saw drill and (f) step-core-candlestick drill [13]

The major factor in determining of the diamond drill bit efficiency is the working part of the diamond drill bits. Fig. 4 shows main parameters of the drill bit cutting part: $h$ - the height of the diamond layer $(\mathrm{mm}) ; b$ — the width of the diamond layer $(\mathrm{mm}) ; c_{e}$ — the external cutting clearance (distance from the outer cylindrical surface of diamond part to the base) (mm); $c_{i}$ - the internal cutting clearance (distance from the inner diamond surface to the base) $(\mathrm{mm})$. The diamond drill surface performs main work of cutting and the cylindrical surfaces make the calibration during the drilling process. The size of the diamond part of drill bit based on several conditions: the height $(h)$ increase and width $(w)$ improve the tool life. However, diamond part width decreasing leads to reducing the thrust force, volume of dispersible material, makes better chip scrap withdrawing from the cutting zone, reduces energy consumption and improves the processing quality [17]. It was experimentally established that wear of diamond layer takes place during cutting process, both at the end and cylindrical surface. Fig. 5 shows the wear character of diamond core drill bit, $4 \mathrm{~mm}$ in diameter with metal bonding Ml. The most intensive wear is at the drill edge surface. By the time when the wear along the drill axis was $2,2 \mathrm{~mm}$, the wear in the radial direction was only $0,1 \mathrm{~mm}$. The wear in the axial direction in $20 \ldots 30$ times more than the radial wear. This gives an idea of which should be the size of the diamond part. Indeed, at the edge surface of the drill, creates the condition of self-sharpening mechanism of wear. At the same time, the radial cutting force is not enough to break the tops of the single diamond grains. Grains at the cylindrical surface exposed to diffusion wear at the grain tips and after that, they transform into planar platform. Such surfaces work as radial bearing and this affects the surface quality. It was noticed by Krishnaraj et al [18] the significant surface damage around hole edge at the exit side of workpiece after observing of 120 holes. The improving of the cutting conditions can be achieved by using of lubricating and cooling fluid [19]. However, the existing drill bits geometry essentially precludes ingress of any liquid directly to the cutting zone. 


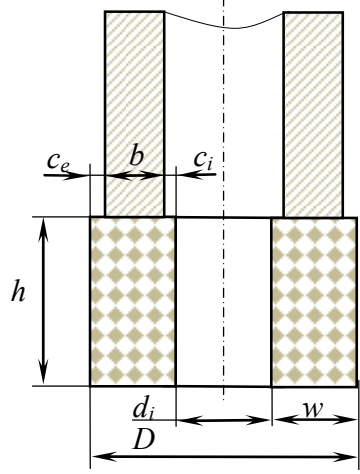

Fig. 4. The geometry of the diamond core drill

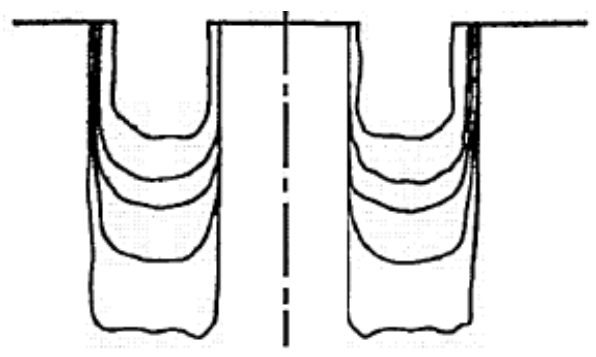

Fig. 5. The effect of drill bit wear at the cutting area [17]

Another important factor, which has influence on the cutting process, is the cutting force. Thrust and torque have impact on cutting temperature, tool wear, surface roughness, and workpiece damage. Cutting force mainly depends on feed rate and cutting speed. The CFRP laminates, thus high thrust force leads to delamination between layers. The edge of hole is destroyed at the inlet and outlet of the workpiece, some fibers are not cut and the hole remains not opened and other problems exist. The correlation between such characteristics as tool geometry, thrust and delamination are one of the most famous lines of researches in this area today $[7,8,11 \ldots 16,20]$. However, there are also the constructive factors, which affect the cutting force. The studies $[21,22]$ indicate the strong influence of grit size of abrasive fracture. When abrasive size grows from 0,03 to $0,25 \mathrm{~mm}$ of grain diameter, the thrust decreases approximately from 370 to $150 \mathrm{~N}$ respectively. Therefore, the grit size changing could be a good way to reduce forces. Nevertheless, the increasing of grain size results in high roughness of surface [22...24].

According to the author's experiments in this article, the piston formed in space of the tool, has negative effect on the drilling process. The CFRP used in this experiment made by Hexion epoxy die Epikote 04695/1 and hardener Epikure 05357. The plate has thickness of $4 \mathrm{~mm}$ and consists of 10 layers; each layer has thickness of $0,4 \mathrm{~mm}$ and formed as a fabric, where bundles of fibers intertwined at angle of 90 degrees. The core drill bit has the drill diameter of $6 \mathrm{~mm}$, diamond mark AS $32 \mathrm{H}$ on galvanic coupling with $100 \%$ diamond concentration and of 200/160 grit size, production of "Poltava Diamond Tools". The drilling was performed using the three axis CORTINI M500/F1 vertical CNC milling machine. Four-component Kistler dynamometer (type 9272) and Kistler type 5019 multichannel charge amplifier used for cutting forces measurements. In the process of each hole drilling, the inner space of tool did not clean. Cutting speed and feed rate are $30 \mathrm{~m} / \mathrm{min}$ and $0,02 \mathrm{~mm} / \mathrm{rev}$, respectively.

In the first holes the thrust force increases smoothly (Fig. 6). In the following holes it can be observed that the thrust speeds sharply at the initial stage of drilling that exceeds the mean value of thrust for the stable cutting stage (from 2 to 8 seconds of cutting time). Obviously, the piston is firmly fixed in the tool at the beginning of drilling process (Fig. 7) and for its further movement is necessary to apply a certain force. When the fifth hole is drilled, the thrust increased more than two times. There are two reasons of core blocking:

1. Carbon fibers have highly elastic properties. The carbon fibers are compressed during the cutting process and after finishing the cutting process fibers recovered its size and position and it makes the piston wider.

2. Low heat resistance of CFRP. The die undergoes the thermal decomposition and melting during tooling process. After the drilling process, the piston cools down and consolidates firmly in the cavity of the drill bit. In any case, such thrust increase leads to the delamination or other damage growing on the exit side of the die, also can be the reason of thin details breaking. On the other hand, the cleaning of tools greatly reduces the process productivity. 


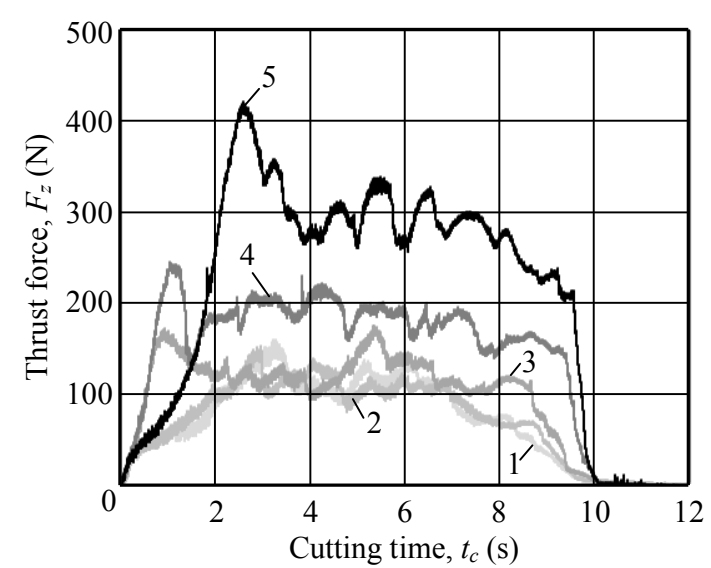

Fig. 6. Influence of core blocking on the thrust force

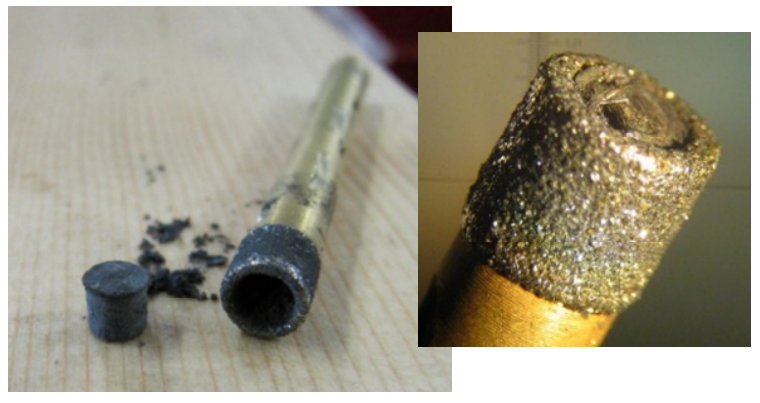

Fig. 7. The photos of core blocking

Another experiment concerning diamond drilling of CFRP [20] showed the thermal obstacle. The drilling must be performed at low axial feed, high cutting speed and small abrasive grain size for highquality surfaces and edges of hole. This combination provides high level of heat in the cutting zone. All polymers have low heat resistance and low thermal conductivity. The heat from the chip deformation and friction is concentrated on surface and goes in depth of the die very slowly. This results in thermal degradation of the polymer. Most of heat goes into the drill bit and it reduces the tool life. Thus, the obtaining the high quality surface in the polymers tooling using diamond tools is almost impossible.

The Aim. To improve the process efficiency of diamond drilling of composite polymers the main aim of this study was to develop new designs of diamond drill bits, which will provide the following tasks:

- to create possibility for effective application of a cooling liquid;

- to improve condition for the chip scrap pulling out;

- to remove or cut down the thermal defects;

- to reduce the surface roughness and the damage of hole edges;

— to increase the tool life;

- to eliminate the problem of core blocking for core drill type tools.

The established tasks have been achieved by changing the drill bits components affecting on the cutting process. It can be concluded from the above analysis that such components are: the cutting part geometry and the grit size. In other words, the new designs are based on changing diamond part, on the interrupted cutting conditions and on the manipulation of the grit size.

Materials and Methods. Using the research results, the set of new designs of diamond drill bits were developed. All inventions are protected by state patents. New designs were obtained by modifying of the cutting part geometry and by manipulation of the grain size. Table 1 shows three designs of the rod drill and three designs of the core drill (left and right, respectively). All designs combine several common features:

- Multi-layered diamond part;

- Interrupted cutting conditions;

- Convenient geometry for the coolant supply and chip scrap pulling out;

- The system of gradual cutting load for drill rod.

The design of each drill consists of metal or alloy base 1 with the diamond part 2 on the one side. The diamond part has two or more diamond layers (only two layer for each drill as example presented in table 1), which have different abrasive fraction. The layer of large grit size 3 always located closer to the rotation axe of the drill, the layer of small grit size 4 situated on larger distance from axial line. 
The new constructions of diamond drill bits

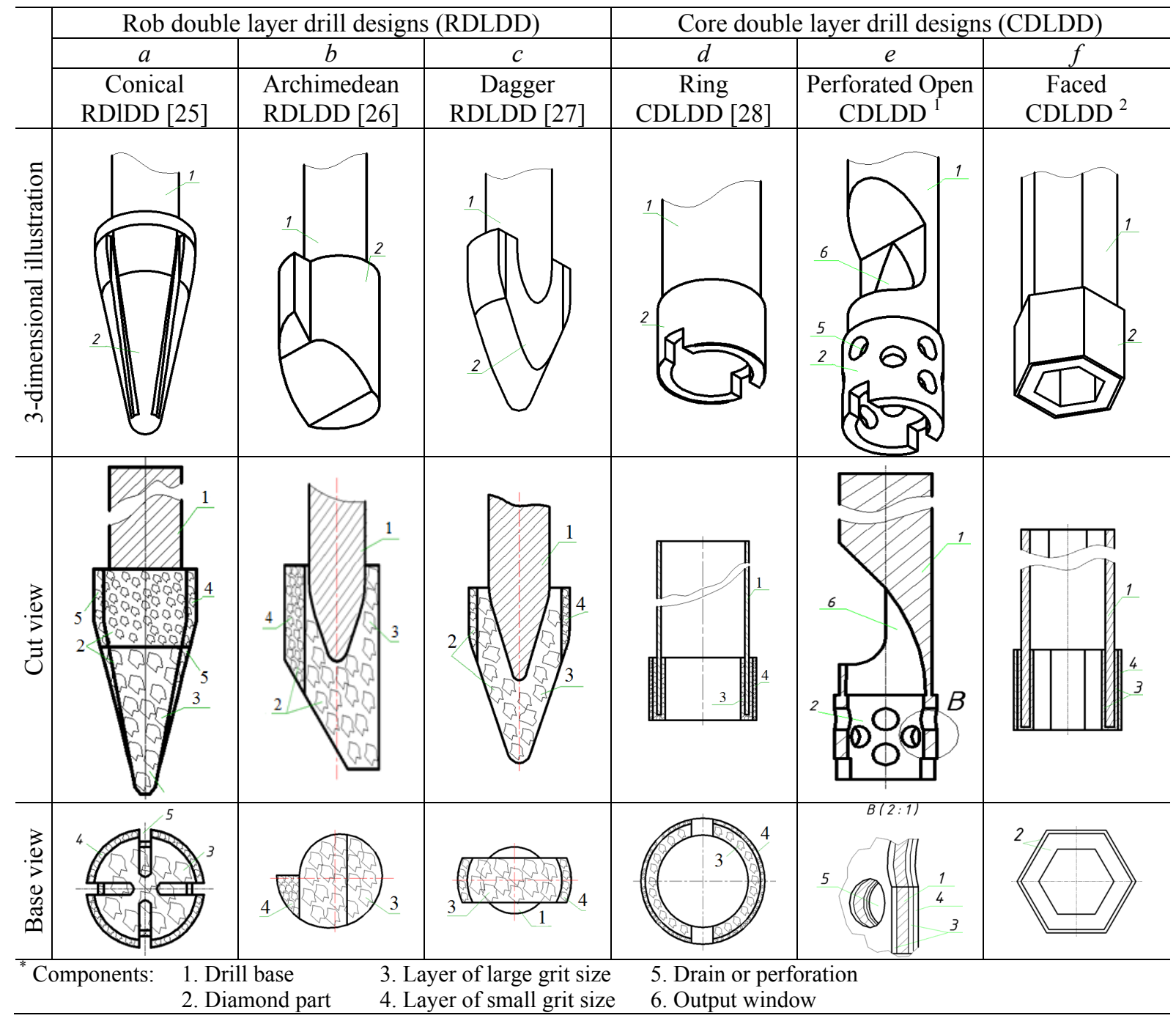

Conical drill bit with drainage channels (Table 1,a) performs a cutting process gradually. This creates particular advantage while drilling fine details. When the backside of diamond part comes in processed plate, the front part of the drill has finished cutting process and does not have force effects. In this case, the cutting forces are generated only by certain part of the drill, not by all diamond part immediately. Such cutting distribution leads to a significant reduction in thrust and torque. According to investigations $[7,8,11 \ldots 16,20]$ this tends to reduce of the delamination factor and other damage near to the edges of hole. The drilling process by the tool can be divided into two stages (Fig. 8, a): 1) cutting by diamond layer 2 , and 3 ) cutting by diamond layer 4 . From the review mentioned above is well known that large diamond grains are more productive in the process, so layer with large grit size 3 removes the main bulk of the material. It is also known that small grains suitable for creating a low surface roughness, so diamond layer 4 removes the last material layer. The drainage channels 5 provide interrupted cutting condition; it reduces the temperature in the cutting zone. In addition, drains provide an opportunity to bring the cooling fluid directly to the cutting zone. The chip scrap migrates

\footnotetext{
${ }^{1}$ During the patent application process. Registration number u201509355.

${ }^{2}$ During the patent application process. Registration number u201509758.
} 
along the conical surface until entering to the drainage channel, after the chip scrap is washed out of the channel due to the high pressure of coolant. This, again, decreases the thermal stress of the process and reduces clogging of the cutting surface of the tool. The conical drill bit is appointed for drilling of thin structures, where there is no opportunity to use the backup plate.

The Archimedean drill (Table 1,b) has an eccentric shape. The hole surface is generated by spike with a small graininess 4 , while the main work performing by the layer with a large grain size 3 (Fig. 8, $b$ ). The interrupted cutting condition, coolant supply and chip scrap pulling out occurs due to the truncated base. A cone with vertex at the point of zero cutting speed appears under drill during drilling process. The permanent absence of the material around the top facilitates the crushing of vertex without high axial loading. The cooling time is always larger than the cutting time and this provides sufficient time to fill the space by cooling liquid and wash out the chip scrap. This tool is particularly suitable for deep hole drilling.

The dagger drill (Table 1,c) drills the material like a conical drill bit, but it has two empty zones in its design instead of the drainage channel (Fig. 8, c). This reduces the cutting/cooling ratio, increases the possibility of chip output. Dagger is recommended for drilling of material with very low thermal resistance.

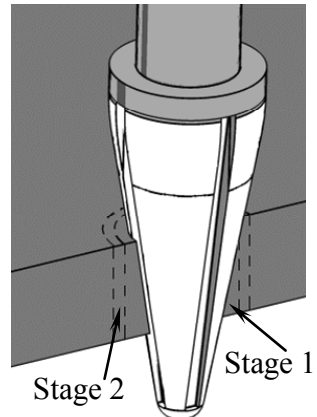

$a$

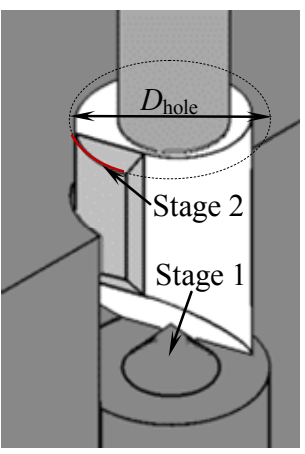

$b$

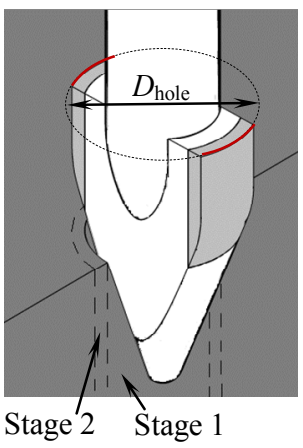

$c$

Fig. 8. The scheme of the cutting process: $a$-Conical RDLDD; $b$-Archimedean RDLDD; $c$-Dagger RDLDD

Ring drill (Table 1,d) operates as an ordinary core drill, but has two layers of grit and a groove at the bottom for interrupted cutting condition, that has already been described above. Diamond part can be mounted on the ring of metal base or sputtering by thin layer on the surface of the metal base. Ring drill is simple in manufacturing, low cost, effectively replaces the ordinary core drill in any conditions.

Perforated open drill (Table 1,e) has a groove in the bottom and a perforation in the wall of diamond part and a tunnel in the metal base. The perforation cools the die, because at the moment of its passage relative to the treatment surface, the cutting process and friction are absent there. It also provides an opportunity for chip scrap pulling out from the cutting zone. As can be seen from the Fig. 6, the significant increase in thrust was observed after drilling of third hole (cutting length is $12 \mathrm{~mm}$ ). This associated with the presence of the long pistons inside the drill. Therefore, it is better avoid the creation of long pistons. This condition is achieved by the gradual output of piston through the tunnel in the metal base. Such design provides stable traction in multiple drilling without drill space cleaning and is recommended for the treatment of elastic materials where the core blocking is quite possible.

The faceted drill (Table 1, f) has multiple layers of graininess like all previous drill bits (the advantages of this technique have been already described above) with faceted inner and outer perimeter instead the ring form. The interior surface contacts with the piston only at the points where the circle touches the polyhedron. This reduces the fixing strength of piston in the inner space of drill bit. An elastic recovery of the material occurs after cutting edge passing when processing many types of elastic materials including carbon composites. Instead of cutting, the elastic material compresses and 
recovers its shape after passage of the instrument. As a result, the diameter of the hole is often less than the drill diameter. The outer polyhedron besides coolant supplying and chip scrap pulling out also helps eliminate the negative effects of elastic deformations. The faceted drill has plurality of cutting edges; such geometry many times repeats the process of establishing of the predetermined diameter. The model is simple in manufacturing, low cost and used to perform precise diameter hole drilling in highly elastic materials.

These constructions can be performed using methods of electroforming, powder metallurgy, plasma spraying, ion plasma deposition and others. The diamond part can be fixed to metal base using special hat or set directly, as shown in figures in Table 1. The thickness ratio between the layer 3 and layer 4 depends on type and diameter of drill bit. For example, the ratio for the drill rod is $10 / 1$ and for the core drill bit with drill diameter of $5 \mathrm{~mm}$ is $20 / 1$. The angles, slopes and eccentricity of a rod drill can be calculated according to the characteristics of a die and critical cutting forces. The width of drainage channels, the diameter of perforation and the size of empty zones can be calculated considering the micro cycle of heating/cooling relative to known heat equations [4...6].

Conclusions. The new and more efficient designs of diamond drill bits were proposed in this study based on the literary analysis and the author's experiments and modeling. The known obstacles for successful application of diamond drilling tools were considered and other negative circumstances of the drilling operation were established experimentally. Theoretical modeling of new tools allows establishing the following advantages:

— reducing of cutting forces;

- reducing the temperature in cutting zone;

— increasing the tool life;

— improving the quality of surface roughness;

- reducing the damage around the edge of the hole at the inlet and output of die.

The new drill bits designs are also the solution for drilling of thin-walled dies, for deep drilling, for materials with low thermal resistance and highly elastic characteristics.

Acknowledgements. The author wishes to express his deep gratitude to Prof. Luca Settineri and Dr. Paolo Claudio Priarone from DIGER of Politecnico di Torino for the experiment implementation and scientific cooperation with support by Erasmus Mundus program. He also thanks Prof. Vasily Larshin from DMBT of Odessa National Polytechnic University for advices in copyright registration.

\section{Література}

1. Дударев, А.С. Конструкции сверл и фрез для алмазно-абразивной обработки стеклопластиков и углепластиков / А.С. Дударев // Известия ТулГУ. Технические науки. - 2012. - Вып. 1. C. $361-370$.

2. Балыков, А.В. Новое поколение алмазно-абразивного инструмента / А.В. Балыков, С.И. Сухонос // Технология металлов. - 1999. - № 8. - С. $46-48$.

3. Балыков, А.В. Новый алмазно-абразивный инструмент «МонАлит» / А.В. Балыков // ИСОТ. 1999. - № 2.

4. Лищенко, Н.В. Определение температуры прерывистого шлифования / Н.В. Лищенко, В.П. Ларшин, А.В. Якимов / Пр. Одес. політехн. ун-ту. — 2012. — Вип. 2(39). — С. $80-85$.

5. Ларшин, В.П. Температура прерывистого шлифования без принудительного охлаждения / В.П. Ларшин, Н.В. Лищенко // Наукові нотатки. — 2013. - Вип. 41, Ч. 1. - С. 154 - 159.

6. Ларшин, В.П. Определение температуры шлифования при импульсном тепловом потоке / В.П. Ларшин, Н.В. Лищенко // Інформаційні технології в освіті, науці та виробництві. — 2013. Вип. 1(2). - С. $41-49$.

7. Quan, Y. Investigation on drilling-grinding of CFRP / Y. Quan, W. Zhong // Frontiers of Mechanical Engineering in China. - 2009. - Vol. 4, Issue 1. - PP. 60 - 63.

8. Tsao, C.C. Parametric study on thrust force of core drill / C.C. Tsao, H. Hocheng // Journal of Materials Processing Technology. - 2007. - Vol. 192-193. - PP. 37 - 40. 
9. Tsao, C.C. Taguchi analysis of drilling quality associated with core drill in drilling of composite material / C.C. Tsao // The International Journal of Advanced Manufacturing Technology. — 2007. Vol. 32, Issue 9. - PP. 877-884.

10. Tsao, C.C. Investigation into the effects of drilling parameters on delamination by various step-core drills / C.C. Tsao // Journal of Materials Processing Technology. — 2008. — Vol. 206, Issues 1-3. PP. $405-411$.

11. Tsao, C.C. Experimental study of drilling composite materials with step-core drill / C.C. Tsao // Materials \& Design. - 2008. - Vol. 29, Issue 9. - PP. 1740 - 1744.

12. Tsao, C.C. Evaluation of the drilling-induced delamination of compound core-special drills using response surface methodology based on the Taguchi method / C.C. Tsao // The International Journal of Advanced Manufacturing Technology. — 2012. — Vol. 62, Issue 1. — PP. 241 - 247.

13. Tsao, C.C. Evaluation of drilling parameters on thrust force in drilling carbon fiber reinforced plastic (CFRP) composite laminates using compound core-special drills / C.C. Tsao, Y.C. Chiu // International Journal of Machine Tools and Manufacture. - 2011. - Vol. 51, Issue 9. — PP. 740 - 744.

14. Hocheng, H. Comprehensive analysis of delamination in drilling of composite materials with various drill bits / H. Hocheng, C.C. Tsao // Journal of Materials Processing Technology. — 2003. — Vol. 140, Issues 1-3. - PP. $335-339$.

15. Hocheng, H. The path towards delamination-free drilling of composite materials / H. Hocheng, C.C. Tsao // Journal of Materials Processing Technology. — 2005. — Vol. 167, Issues 2-3. — PP. 251 - 264.

16. Hocheng, H. Effects of special drill bits on drilling-induced delamination of composite materials / H. Hocheng, C.C. Tsao // International Journal of Machine Tools and Manufacture. — 2006. Vol. 46, Issues 12-13. - PP. 1403 - 1416.

17. Балыков, А.В. Работоспособность алмазных сверл, изготовленных из различных марок алмазного сырья / А.В. Балыков, Н.Ф. Кирова, А.А. Цесарский // Алмазы и сверхтвердые материалы. 1975. - Вып. 4. - С. 7 - 10.

18. Optimization of machining parameters at high speed drilling of carbon fiber reinforced plastic (CFRP) laminates / V. Krishnaraj, A. Prabukarthi, A. Ramanathan, etc. // Composites Part B: Engineering. 2012. - Vol. 43, Issue 4. — PP. 1791 - 1799.

19. Мурзин, Л.М. Роль смазочно-охлаждающей жидкости в процессе алмазного сверления / Л.М. Мурзин, Ю.Ю. Колосовский // Вісник СевНТУ. Машиноприладобудування та транспорт. 2010. - Вип. 107. - С.161 - 164.

20. Мелентьев, Р.Ю. Особенности механической обработки полимерных композиционных материалов / Р.Ю. Мелентьев, В.В. Натальчишин // Збірник наукових праць Національного університету кораблебудування. - 2013. - № 4(449). - С. $30-34$.

21. Rotary ultrasonic machining of CFRP: A mechanistic predictive model for cutting force / W.L. Cong, Z.J. Pei, X. Sun, C.L. Zhang // Ultrasonics. - 2014. - Vol. 54, Issue 2. - PP. 663 - 675.

22. Рощупкин, С.И. Экспериментальное исследование влияния технологических параметров процесса алмазного сверления неметаллических материалов на силы резания и шероховатость поверхности / С.И. Рощупкин // Вісник СевНТУ. Машиноприладобудування та транспорт. — 2010. Вип. 111. - С. $148-151$.

23. Балыков, А.В. Новые технологии алмазного сверления / А.В. Балыков // Технология металлов. 2003. 一 № 6. - C. $30-32$.

24. Balykov, A.V. Optimization of diamond drilling using an extreme experimental design / A.V. Balykov // Glass and Ceramics. - 2003. - Vol. 60, Issue 7. - PP. 213 - 216.

25. Пат. 88720 Україна, МПК В28D 1/12. Абразивне конічне свердло / Ларшин В.П., Ліщенко Н.В., Мелентьєв Р.Ю.; заявники та патентовласники Ларшин В.П., Ліщенко Н.В., Мелентьєв Р.Ю. № u201313139; заявл. 11.11.2013; надр. 25.03.2014; Бюл. № 6.

26. Пат. 92358 Україна, МПК В28D 1/12, B24D 5/00. Абразивне Архімедове свердло / Мелентьєв Р.Ю.; заявник та патентовласник Мелентьєв Р.Ю. — № u201402925; заявл. 24.03.2014; надр. 11.08.2014; Бюл. № 15 .

27. Пат. 92485 Україна, МПК В28D 5/00, B28D 1/12. Абразивне клиновидне свердло / Мелентьєв Р.Ю.; заявник та патентовласник Мелентьєв Р.Ю. — № u201314191; заявл. 05.12.2013; надр. 26.08.2014; Бюл. № 16.

28. Пат. 86318 Україна, МПК B24D 5/00, В28D 1/12. Абразивне кільцеве свердло / Мелентьєв Р.Ю.; заявники та патентовласники Ліщенко Н.В., Мелентьєв Р.Ю., Ларшин В.П. — № u201308214; заявл. 01.07.2013; надр. 25.12.2013; Бюл. № 24. 


\section{References}

1. Dudarev, A.S. (2012). Designs of drills and mills for diamond processing of polymeric composite materials. Proceedings of the Tula State University: Technical Science, 1, 361-370.

2. Balykov, A.V., \& Sukhonos, S.I. (1999). The new generation of diamond abrasive tools. Tekhnologiya Metallov, 8, 46-48.

3. Balykov, A.V. (1999). The new diamond-abrasive MonAlit tool. ISOT, 2.

4. Lishchenko, N.V., Larshin, V.P., \& Yakimov, A.V. (2012). Evaluation of discontinued grinding temperature. Odes 'kyi Politechnichnyi Universytet. Pratsi, 2, 80-85.

5. Larshin, V., \& Lishchenko, N. (2013). Temperature of discontinued grinding without forced cooling. Naukovi Notatky, 41(1), 154-159.

6. Larshin, V.P., \& Lishchenko, N.V. (2013). Grinding temperature determination at impulsive thermal flux. Information Technologies in Education, Science and Production, 1, 41-49.

7. Quan, Y., \& Zhong, W. (2009). Investigation on drilling-grinding of CFRP. Frontiers of Mechanical Engineering in China, 4(1), 60-63. DOI:10.1007/s11465-009-0008-y

8. Tsao, C.C. \& Hocheng, H. (2007). Parametric study on thrust force of core drill. Journal of Materials Processing Technology, 192-193, 37-40. DOI:10.1016/j.jmatprotec.2007.04.062

9. Tsao, C.C. (2007). Taguchi analysis of drilling quality associated with core drill in drilling of composite material. The International Journal of Advanced Manufacturing Technology, 32(9), 877-884. DOI:10.1007/s00170-006-0414-9

10. Tsao, C.C. (2008). Investigation into the effects of drilling parameters on delamination by various step-core drills. Journal of Materials Processing Technology, 206(1-3), 405-411. DOI:10.1016/ j.jmatprotec.2007.12.057

11. Tsao, C.C. (2008). Experimental study of drilling composite materials with step-core drill. Materials \& Design, 29(9), 1740-1744. DOI:10.1016/j.matdes.2008.03.022

12. Tsao, C.C. (2012). Evaluation of the drilling-induced delamination of compound core-special drills using response surface methodology based on the Taguchi method. The International Journal of Advanced Manufacturing Technology, 62(1), 241-247. DOI:10.1007/s00170-011-3785-5

13. Tsao, C.C., \& Chiu, Y.C. (2011). Evaluation of drilling parameters on thrust force in drilling carbon fiber reinforced plastic (CFRP) composite laminates using compound core-special drills. International Journal of Machine Tools and Manufacture, 51(9), 740-744. DOI:10.1016/j.ijmachtools.2011.05.004

14. Hocheng, H., \& Tsao, C.C. (2003). Comprehensive analysis of delamination in drilling of composite materials with various drill bits. Journal of Materials Processing Technology, 140(1-3), 335-339. DOI:10.1016/S0924-0136(03)00749-0

15. Hocheng, H., \& Tsao, C.C. (2005). The path towards delamination-free drilling of composite materials. Journal of Materials Processing Technology, 167(2-3), 251-264. DOI:10.1016/j.jmatprotec. 2005.06.039

16. Hocheng, H., \& Tsao, C.C. (2006). Effects of special drill bits on drilling-induced delamination of composite materials. International Journal of Machine Tools and Manufacture, 46(12-13), 1403-1416. DOI:10.1016/j.ijmachtools.2005.10.004

17. Balykov, A.V., Kirov, N.F., \& Tsesarsky, A.A. (1975). The efficiency of diamond drill bits made of different brands of rough diamonds. Almazy i Sverkhtverdye Materialy, 4, 7-10.

18. Krishnaraj, V., Prabukarthi, A., Ramanathan, A., Elanghovan, N., Kumar, M.S., Zitoune, R., \& Davim, J.P. (2012). Optimization of machining parameters at high speed drilling of carbon fiber reinforced plastic (CFRP) laminates. Composites Part B: Engineering, 43(4), 1791-1799. DOI:10.1016/ j.compositesb.2012.01.007

19. Murzin, L.M., \& Kolosovsky, Y.Y. (2010). The role of the lubricant-cooling liquid in the process of diamond drilling. SevNTU Journal: Mechanical Instrumentation and Transport, 107, 161-164.

20. Melentiev, R.Yu., \& Natalchishin, V.V. (2013). Specific features of mechanical processing of polymeric composite materials. Collection of Scientific Publications of the National University of Shipbuilding, 4, 30-34.

21. Cong W.L., Pei Z.J., Sun X., \& Zhang C.L. (2014). Rotary ultrasonic machining of CFRP: A mechanistic predictive model for cutting force. Ultrasonics, 54(2), 663-675. DOI:10.1016/j.ultras.2013.09.005

22. Roschupkin, S.I. (2010). Experimental research on the influence of technological parameters of the process of diamond drilling of non-metallic materials on cutting forces and surface roughness. SevNTU Journal: Mechanical Instrumentation and Transport, 111, 148-151.

23. Balykov, A.V. (2003). New technologies of diamond drilling. Tekhnologiya Metallov, 6, 30-32. 
24. Balykov, A.V. (2003). Optimization of diamond drilling using an extreme experimental design. Glass and Ceramics, 60(7), 213-216. DOI:10.1023/A:1027383007954

25. Larshyn, V.P., Lischenko, N.V., \& Melentiev, R.Yu. (2014). Abrasive conical drill. Ukraine Patent: UA 88720.

26. Melentiev, R.Yu. (2014). Abrasive Archimedean drill. Ukraine Patent: UA 92358.

27. Melentiev, R.Yu. (2014). Abrasive dagger drill. Ukraine Patent: UA 92485.

28. Lischenko, N.V., Melentiev, R.Yu., \& Larshyn, V.P. (2013). Abrasive annular drill. Ukraine Patent: UA 86318.

Received November 11, 2015

Accepted December 21, 2015 